\title{
O QUE VOCÊ TRAZ À MESA?
}

Coberto de orgulho, o pai de Roberto embalou o bebê recém-nascido vislumbrando o futuro que sonhara para si mesmo: "Ele vai estudar na GV ou na Poli”. Foi assim e até mais. Roberto formou-se engenheiro mecânico pela Poli, estagiou em uma multinacional e foi efetivado antes de se graduar. Aos 27 anos, já analista sênior, fez o Ceag, patrocinado pela empresa, para suprir os conhecimentos de Administração que lhe faltavam. Roberto chegou a gerente do Departamento de Orçamentos aos 29 anos. Motivado por modelos e mentores, decidiu fazer um MBA nos EUA. Candidatou-se para várias escolas de negócios, entre as mais bem conceituadas segundo a Businessweek e, sendo aceito em três, optou por Wharton.

Conheço Roberto quando ele decide participar de alguns processos de recrutamento de empresas brasileiras. Ele é mais um entre os 35 candidatos que entrevistarei. Para Roberto, e todos os outros pretendentes, tenho apenas três perguntas: o que você traz à mesa, o que deseja e como esta empresa se encaixa em seus planos. Desejo saber qual o seu posicionamento, pois é isso que diferencia um candidato de outro. O posicionamento é a mais importante peça de comunicação de um profissional, pois define como o indivíduo se vê, quais suas aspirações, e indica a razão da conversa em questão.

Roberto traz mais à mesa do que formação educacional e trajetória profissional diferenciadas: traz curiosidade por problemas complexos, capacidade de aprender com erros, paixão por modelos matemáticos e uma boa leitura de cenários organizacionais. Traz ainda ambição bem colocada, valores sólidos, uma boa dose de audácia e capacidade de rir de si mesmo. O que o candidato traz à mesa é sua dimensão completa, quem de fato é, e não apenas o que fez ou os cargos que colecionou.

Já a segunda dimensão do posicionamento revela as aspirações do indivíduo. Espero que as aspirações de um candidato sejam maiores que crescer na empresa. No caso de Roberto, seu desejo é poder fazer o que gosta e desenvolver novas habilidades: usar modelos para resolver problemas complexos e aprofundar-se na gestão de pessoas, sendo exposto a situações em que tenha que negociar. As aspirações podem dizer respeito só ao curto prazo ou também incluir o longo prazo. Já entrevistei candidatos com um contorno bem definido quanto a seus desejos de longo prazo, mas esses são casos mais raros, e não raramente algumas pessoas no Brasil temem ser percebidas como arrogantes ao compartilhar suas aspirações profissionais.

A última parte do posicionamento explica onde o interlocutor entra na história do entrevistado. No caso de Roberto, que fez sua lição de casa e pesquisou sobre a empresa, começamos um diálogo sobre suas hipóteses a respeito das distintas áreas da empresa e o tipo de projeto que cada uma poderia oferecer. Uma conversa sobre as possibilidades que fazem sentido no próximo capítulo profissional de Roberto. Onde na empresa poderíamos unir as necessidades organizacionais aos anseios de Roberto, já que a escolha é sempre bilateral, tanto da empresa como do candidato.

O posicionamento permite uma conversa profissional estruturada e requer autoconhecimento e reflexão. Alguns candidatos repetem um discurso de elevador, com frases decoradas e cheias de lugares-comuns, no anseio de aproveitar ao máximo a atenção de seu interlocutor. É esse tipo de ansiedade que afasta o candidato de seu objetivo. O discurso decorado e repetido sem levar em conta com quem se dá o diálogo é muito distante do posicionamento, que por sua vez transmite a segurança de quem o candidato é e a determinação de onde quer chegar.

O diálogo com Roberto levou-o a uma entrevista bem-sucedida, o que não foi o caso de outros candidatos, todos muito bem formados. O que fez a diferença a favor de Roberto foi seu posicionamento. E você, sabe o que traz à mesa? 